\title{
ASSESSMENT OF MYOELECTRIC MANIFESTATIONS OF MUSCLE FATIGUE DURING REPETITIVE ISOMETRIC VOLUNTARY CONTRACTION IN BOYS AGED 12-14
}

\author{
Abir Samanta $^{1 \mathrm{ABCD}}$, Sabyasachi Mukherjee ${ }^{1 \mathrm{AD}}$ \\ ${ }^{1}$ Lakshmibai National Institute of Physical Education \\ Authors' Contribution: A - Study design; B - Data collection; C - Statistical analysis; D - Manuscript Preparation; E - Funds Collection
}

Corresponding Author: Abir, Samanta, E-mail: abirphyyoga137@gmail.com

Accepted for Publication: March 20, 2021

Published: March 25, 2021

DOI: $10.17309 /$ tmfv.2021.1.07

\begin{abstract}
Aim: To study the peculiarity of electromyography signal characteristics alternation using different sEMG parameters during repetitive voluntary isometric fatiguing contraction in adolescent boys.

Materials and methods. 12 subjects with height $148.75 \pm 10 \mathrm{~cm}$; Mass $38.9 \pm 7.9 \mathrm{~kg}$; age -12 to 14 years were recruited. The sEMG signal alteration of external oblique, rectus abdominis, erector spinae muscles during a fatiguing plank were analyzed. A separate one-way repeated measures ANOVA was used to test the statistical significance of task time and electromyography parameters of the global core muscle in the pre-, during- and post-fatigue plank test. Oneway Friedman ANOVA was applied for Shapiro-Wilk p $<0.05$. The Pearson product-moment correlation coefficient with bivariate linear regressions analysis was performed between the pre-pre fatigue and post-post fatigue amplitude mean and standard deviation values. The Spearman correlation coefficient between amplitude and endurance time both in the pre- and post-fatigue state was conducted.

Results. The mean value of rectified amplitude increased $(p<0.05)$ for all muscles, the standard deviation of amplitude and total spectral power increased significantly $(\mathrm{p}<0.05)$ for all muscles except the erector spinae muscle $(\mathrm{p}>0.05)$. The power at normalized low frequency significantly changed $(p=0.05)$ in the erector spinae muscle. A significant change in normalized low frequency for agonist/synergist $(\mathrm{p}=0.02)$ and agonist/antagonist muscles $(\mathrm{p}=0.05)$ was observed. The average amplitude value had a significant positive and linear relationship with the amplitude variability both in the pre- to post-fatigue state, except the erector spinae muscle. The time to task failure was not correlated ( $\mathrm{p}>$ $0.05)$ with the sEMG amplitude.

Conclusions. Increased sEMG amplitude resulted mainly from rapid additional motor unit recruitment and rate coding during muscle fatigue. The reduction of conduction velocity might affect the spectral power with a spectral shift towards low-frequency. Increased variability, agonist/antagonist co-activity during fatiguing contraction might extend the holding time. The postural fatiguing task/plank increases multiarticular joint function by involving several joints and muscles, increases variability in the contribution of synergist muscles. This factor provides an intuitive explanation about the absence of a relationship between endurance time and sEMG amplitude changes.

Keywords: motor-unit, rate coding, conduction velocity.
\end{abstract}

\section{Introduction}

The Surface Electromyography (sEMG) based measurement of "myoelectric manifestations of muscle fatigue" is meaningless if the receiver has a lower potential to understand the reliability and the information contained in the electrophysiological signals viz. muscle fiber propagation velocity, sEMG amplitude or frequency spectrum etc. as it also required technological proficiency. Significant gap between engineers and exercise physiologist/physical education

(C) Samanta, A., Mukherjee, S., 2021. teachers often observed in terms of barriers in sEMG signal interpretation is concern. The gap resulted mainly from nonfamiliar language and lack of technical background related to the application, signal processing and information extraction algorithms. Lack of knowledge in mathematics and biophysics is a significant educational barrier among physical education teachers often make it challenging for basic signal interpretation (Campanini, Disselhorst-Klug, Rymer, \& Merletti, 2020; Felici \& Del Vecchio, 2020)

Muscular strength and endurance (static) is fundamental motor abilities developed significantly among adolescents in 
the age group of 12-14 yrs. (Ivashchenko, Cieślicka, Nosko, \& Malyshev, 2019; Ivashchenko, Kapkan, Khudolii, \& Yermakova, 2017; Khudolii, Ivashchenko, Iermakov, Veremeenko, \& Lopatiev, 2019). The global axial skeleton stabilizing muscles play an important role during physical activities. The weakness of these postural muscles may contribute to the progression of low back pain as it is crucial to lumbopelvic stability. It is important to understand the central/peripheral system approach on neuromuscular fatigue with the growth and maturation effect on it in sports science. Inflation in sEMG amplitude usually observes during submaximal fatiguing contraction (Cardozo, Gonçalves, \& Dolan, 2011) with conflicting results varying from increase (Gentil, Oliveira, de Araújo Rocha Junior, do Carmo, \& Bottaro, 2007), no difference (Lindstrom, Stefan, \& Lexell, 2006), to decrease muscle activation (Gerdle B, Karlsson S, Crenshaw, Elert, \& Friden, 2000). Increase in agonist-antagonist co-contraction during isometric fatiguing contraction among children might be caused by lower strength (Grosset, Mora, Lambertz, \& Perot, 2008) but not accepted by another study (Kellis, \& Unnithan, 1999).

The measurements of muscle fatigue usually performed during isometric contraction with a constant force, which is considered the "bench-test" condition. The "myoelectric manifestations of muscle fatigue" can be defined as the inability to maintain a given isometric contraction level and it is related to the endurance time with a relative sEMG features alteration from the very beginning of the contraction (Campanini, Disselhorst-Klug, Rymer, \& Merletti, 2020). The retention time of the plank task could reliably estimate isometric core muscle endurance and test core stability in children (Boyer, Tremblay, Saunders, McFarlane, Borghese, Lloyd, \& Longmuir, 2013). First time De Blaiser et al. (2018) reported that the plank test is valid and reliable to measuring global core muscle fatigue. They also stated that the past research studies intended to measure the validity and reliability of plank test was implemented sEMG as a reference technique designed to evaluate the parameters that failed to represent muscle fatigue.

Objectives: Despite the importance, few studies on exercise induced muscle fatigue in children and adolescents are available that makes it difficult to understand the neuromuscular components of pediatric muscle fatigue. Patikas et al. (2018) reported in their systematic review that previously cited research articles associated with exhaustive sub/maximal contraction induced muscle fatigue in children and adolescents revealed the requirement of more research in pediatric fatigue. The most study used only the normalized Root Mean Square value for muscle fatigue analysis. But the sEMG signal waveform cannot provide a valid conclusion about 'Muscle Fatigue' if we use a single sEMG parameter for a heterogeneous muscle group (Duchêne \& Goubel, 1990). To our best information about existing literature on sEMG based muscle fatigue assessment, there are no such studies which evaluated myoelectric manifestation of core muscle fatigue extensively in children using exhaustive Plank test. Therefore we aimed to study the peculiarity of electromyography signal characteristics alternation using different sEMG parametres during repetitive voluntary isometric fatiguing contraction in adolescent boys.

\section{Hypotheses:}

Based on the analysis of previous sEMG fatigue studies we hypothesized that:
1. $\mathbf{H}_{0}: \mathbf{X}_{1 \text { st Plank }}=\mathbf{X}_{\text {2nd Plank }}=\mathbf{X}_{3 \text { rd Plank }} ; \mathbf{H 1}$ : At least one mean value on these selected parameters would be statistically distinguishable. The temporal alteration of selected sEMG signal parameters (Average Rectified EMG (ARV) $[\mu \mathrm{V}]$, EMG Standard Deviation (SD EMG) $[\mu \mathrm{V}]$, Total Spectral Power (TSP) $[\mu \mathrm{V} 2]$, Normalized Low Frequency (N.LF) [\%]) of External Oblique (EO), Rectus abdominis (RA) and Erector Spinae (ES) muscle, RA/EO (Agonist/Synergist) N.LF Ratio, RA/ES (Agonist/Antagonist) N.LF Ratio and the endurance plank time during fatiguing isometric voluntary contraction were analyzed separately.

2. $\mathbf{H}_{\mathbf{0}}: \mathbf{R}=\mathbf{0} \cdot \mathbf{H}_{\mathbf{1}}$ : The mean amplitude value of the sEMG signal was expected to have Gaussian probability distribution and it may show a significant positive and linear relation with absolute variability of sEMG amplitude. Pearson product-moment correlation coefficient (R). sEMG undergo non-uniform changes with increase variability (phase shift) during isometric fatiguing contractions.

3. $\mathbf{H}_{\mathbf{0}}: \mathbf{r}=\mathbf{0} . \mathbf{H}_{\mathbf{1}}$ : Significant Spearman correlation coefficient ( $r$ ) between ARV amplitude with Endurance time both in pre and post fatigue state was expected.

\section{Materials and methods}

\section{Study participants}

Sample size calculation: The sample size (n) was calculated based on the Average Rectified Value (ARV) of the Rectus abdominis muscle activity acquired in a pilot study with three children (Silva et al. 2020). We used ARV for sample size calculation because ARV is significantly less variable and reliable when measuring the core muscle activity (Hibbs et al. 2011). We included the pilot data in the main data set. The sample size was calculated using the $\mathrm{G}^{\star}$ Power (Version 3.1.9.2, Kiel University, Germany) application, for $80 \%$ power at an alpha level of 0.05 . This calculation provided a sample size of 12 for this study.

Power Analysis: We also analysed post hoc power based on 12 samples sEMG ARV amplitude data $G^{*}$ Power (SPSS $\eta_{\mathrm{p}}{ }^{2}$ ): Statistical test $=$ ANOVA: Repeated Measures, within factors; $\alpha$ err probability $=0.05$; Number of group $=1$; Number of measurements $=3$; Nonsphericity correction $\varepsilon=1$. Effect size $\left(G^{*}\right.$ Power- $\left.f\right)$ and estimated Power $(1-\beta$ err probability) were for EO-(f) $=1.49,1-\beta$ err probability $=0.99$; $\mathrm{RA}-(\mathrm{f})=1.06,1-\beta$ err probability $=0.99$; ES-(f) $=0.58$, $1-\beta$ err probability $=0.61$. Moalla et al. (2007) also reported that twelve healthy male children is necessary to find a mean difference in sEMG parameters during the postural fatiguing task.

Therefore a total of 12 subjects were included in the study. The subjects were school-going children aged between age-12 to 14 years (Khudolii, Ivashchenko, Iermakov, Veremeenko, \& Lopatiev, 2019) (height $148.75 \pm 10 \mathrm{~cm}$; Mass $38.9 \pm 7.9 \mathrm{~kg}$ ) and they had more than three months of previous experience with the practice of different yogic exercises. The children were randomly selected from Ram Krishna Vidya Mandir Ashrama (RKVM)-Sharada Balgram, Gwalior (M.P).

Inclusion criteria: Prior to the collection of data, the children were requested to recognize their preferred writing hand, which was contemplated their dominant arm. All children were right-hand dominant (Silva et al., 2020). We collected the sEMG data of core muscle only from the right 
side in subjects with dominant right-hand for fatigue analysis because: 1 . The fatigue indexes are significantly sensitive and evident in the right than left-handed subjects. The fatigue indexes are also less apparent in left than in right-handed subjects (Merletti, De Luca, \& Sathyan, 1994). 2. The adaptation of the Motor Unit (MU) pool in the dominant muscle due to daily preferential use allows for more effective force production at low firing rates by increase the percentage of Type-I fibers resulting in twitch fusion at lower MU firing rates (Adam, De Luca, \& Erim, 1998), although the previous study on hip-abductor fatigability reported non-significant results between dominant and nondominant side (Jacobs, Uhl, Seeley, Sterling, \& Goodrich, 2005).

No previous history of Neuro/Myo pathological disorders and Postural Spinal deformities were reported during data collection. Those boys were clinically tested in (RKVM)Sharada Balgram Health facility.

Consent (Reg. No. PH2010-114, Consent no.-HOD/ Ex.Phy./26/2018-19): Full written advice about the possible risks and discomfort associated with the study was given to the children and local guardian/school principal, they signed the written informed consent form. The study was approved previously by the Departmental Research ethics board of Lakshmibai National Institute of Physical education, Gwalior, India and was conducted following the ethical principles for human research proposed in the Helsinki Declaration.

\section{Study organization}

Fatiguing Plank Protocol: Each child received verbal and visual instructions about the correct posture to perform plank to ensure comfort and familiarity. It may provide better sEMG signal quality during data collection. The Traditional plank protocol used in this study: face lied down and fists on the surface/floor, feet were placed at shoulder width apart, the spine and pelvis in a neutral position. The space between elbows were also shoulder width apart just below the glenohumeral joint. Lift the body up on the forearms and toes (CortellTormo, García-Jaén, Chulvi-Medrano, Hernández-Sánchez, Lucas-Cuevas, \& Tortosa-Martínez, 2017; Schoenfeld, Contreras, Tiryaki-Sonmez, Willardson, \& Fontana, 2014; Bohannon, Steffl, Glenney, Green, Cashwell, Prajerova, \& Bunn, 2018). Participants maintained the proper plank position and throughout the whole period we recorded the sEMG activity of the respective muscles until the test terminated, if the participants could not hold/continue with the correct position because of fatigue and pain. Maximum time limits were recorded with a stopwatch. In summary the children were asked to perform 5 consecutive Surya Namashkara with self-reported pace for warming up, followed by 5 mins. rest. After $5 \mathrm{~min}$. rest they completed three planks (i.e. pre-fatigue (1st plank), during (2nd plank), and post fatigue (3rd plank) with a resting period of 3 mins. in between every plank. Strong verbal encouragements were given to make them motivated to hold a plank to their maximum potential limit. The 3 min rest or interval periods were given between every plank, because: Previous study reported that sufficient recovery from attenuated motoneuron excitability of the muscles induced by low/submaximal isometric fatiguing contraction requires $\leq 240 \mathrm{sec}$., resting period (Heroux, Butler, Gandevia, Taylor, \& Butler, 2016).

Instrument: Preparation of Skin -A single-use cottonwool ball with $60-70 \%$ alcohol-based solution (isopropyl al- cohol) was used for clean the surface of the skin (hair saved) for better conductance.

sEMG-Instrument: ENCEPHALAN - MPA Autonomous Patient Transceiver-Recorder ABP-10. (Medicom MTD Ltd. Research \& Development Limited Company, RUSSIA) sEMG machine was used in this study. We used the "REHACOR" and "MEDICOM" software (British Standard Reg. No. DE/CA37/POL044A4) for sEMG signal processing and raw data analysis. sEMG Electrodes and technical Specifications:: The disposable, oval-shaped, bipolar EMG/ECG surface Electrodes (ANSI/AAMI standard EC12:2000, ISO13485, Medico India) were used. Product Code: MSGLT05MG, Solid, Baking Adhesive - Foam, Enhanced. Dimension: $40 \times 36 \times 1 \mathrm{~mm}, \mathrm{Ag} / \mathrm{AgCl}$ (silver/ silver chloride) sensor, Latex-free, patented gel formula. The inter-electrode distance/spacing were $20 \mathrm{~mm}(2 \mathrm{~cm}$.) in Bipolar fashion. Electrodes and wires were fixed with one-sided white adhesive tape to reduce skin friction and motion artefacts. No sEMG electrodes placement set-up was changed for amplitude estimation during the three planks for each subject. sEMG signals were visually inspected for heartbeat artefacts.

sEMG Settings: The panel of Sweep speed of sEMG was set at $5 \mathrm{~mm} / \mathrm{s}$. sEMG measurement unit: EMG signal ampli-

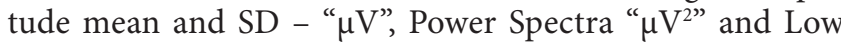
frequency "\%". Analog to digital Convert resolution $=24$; Sampling rate $=1024 \mathrm{~Hz}$; Input dynamic range $>8 \mathrm{mV}(\mathrm{p}$ p); Allowable voltage shift $> \pm 300 \mathrm{mV}$; Noise $<1.4 \mu \mathrm{V}$ (p-p); Sensitivity $=200 \mu \mathrm{V} / \mathrm{mm}$; Common Mode Rejection Ratio $=120$ dB. Processor - Intel Core(TM) 2 Duo CPU E7500 @ 2.93GHz; Memory (RAM) - 2047 MB; System Type - 32-bit offline operating system; LENOVO-PC.

sEMG Parameters: 1. A. ARV-EMG: The addition of all the multiplied values of an arbitrary parameter $\mathrm{X}$ and the probability of these values decide the centroid position in Gaussian distribution. B. SD EMG: Mean-squared deviation of the arbitrary parameter X- the positive square root of the squared deviation of a random parameter $\mathrm{X}$ from its mean value denote the scattering distribution. The whole EMG signal was full-wave rectified, smoothed. 2. N.LF - Normalized low-frequency index was the ratio of the area under the curve in the range of $10-30 \mathrm{~s}(\mathrm{LF})$, to the area under the curve in the range of 2-30 s. LF $=$ N.LF/(TSP-VLF) $100 \%$. 3. Total Spectral Power: The frequencies were evaluated using Discrete-Time Fourier series analysis, with graphs of power or amplitude ratio (Y-axis-Power $\mu \mathrm{V}^{2}$ ) of the oscillation period (X-axis $\mathrm{Hz} / \mathrm{Sec}$.). Total Spectral Power $(\mathrm{TSP})=$ High Frequency $(\mathrm{HF})+$ Low Frequency (LF). sEMG signal processing: The EMG linear envelope and power spectral density (PSD) was calculated using Welch and Bartlett's averaged modified periodogram (Non-parametric) method with 1024 sample analysis, $50 \%$ overlapping windows. In the power spectral density, the sEMG frequency cut-off or the band-pass filter was 10-512 Hz. Further, the energy/power alteration at normalized Low-frequency band $10 \mathrm{~Hz}-70 \mathrm{~Hz}$ was taken for fatigue analysis. As the attenuation of mean power frequency in Spectral parameters from $70 \mathrm{~Hz}$ to $60 \mathrm{~Hz}$ is considered as the progression of myoelectric manifestation of fatigue. The mean power of the frequency below $70 \mathrm{~Hz}$ increases significantly during fatigue. The low frequency increases linearly during the progression of myoelectric manifestation of fatigue (Cardozo, Gonçalves, \& Dolan, 2011). Automated Linear spectrum interpolation algorithm was used to remove 


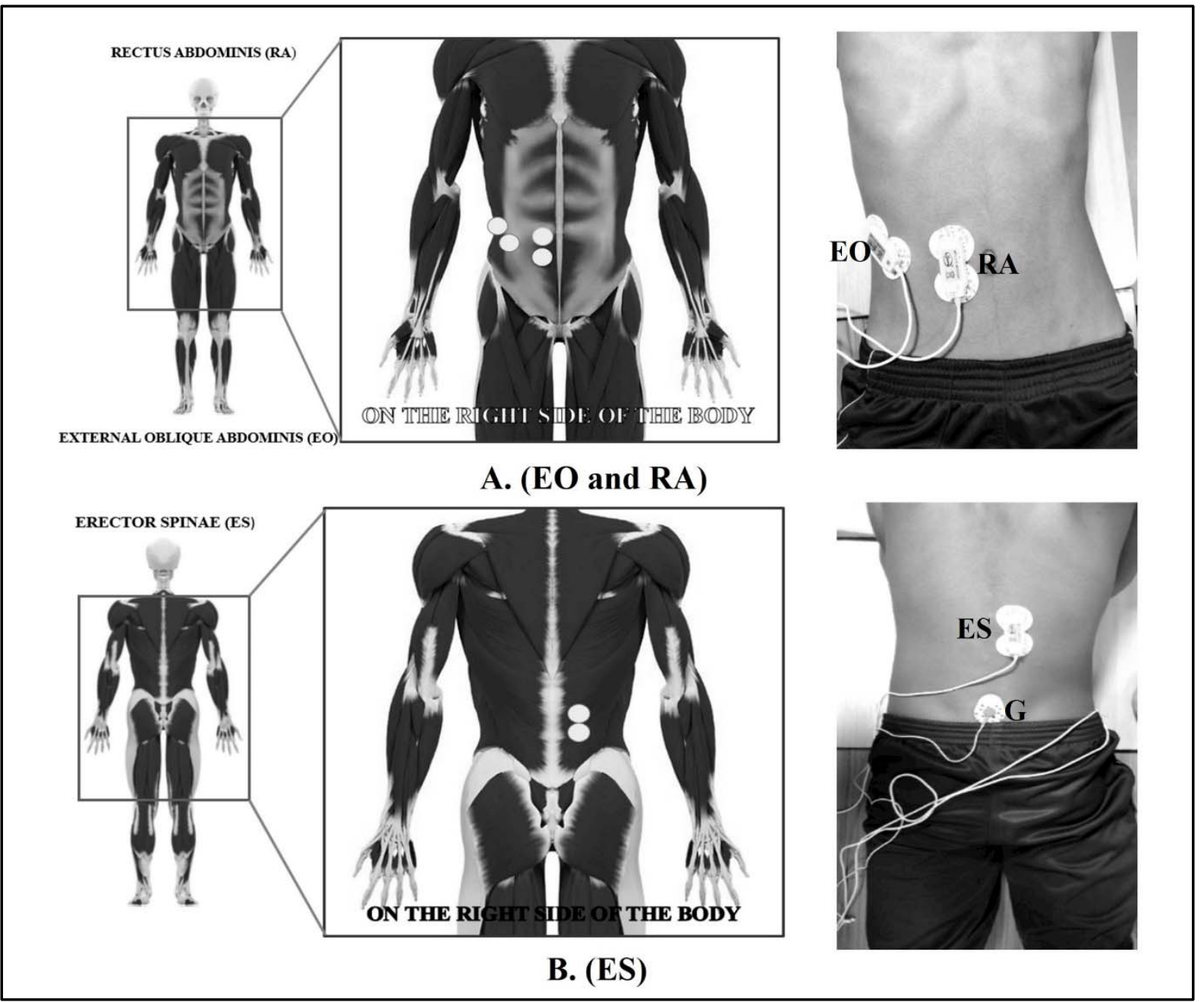

Fig. 1. Electrodes Placement Points: (A) EO and RA; (B) ES muscle. All the sEMG signals were recorderd form the right side of the body

sinusoid interference frequency (cosine function) and timecorrelated power line noise contamination.

Electrodes placement (Right Side dominance): EOlateral portion of rectus abdominis muscle $(\sim 15 \mathrm{~cm}$ lateral to the umbilicus), situated straight over the anterior superior iliac spine, midway between the crest and ribs with oblique or $45^{\circ}$ angle inclination. RA- $\sim 2 \mathrm{~cm}$ lateral to the umbilicus. ES- $\sim 2 \mathrm{~cm}$ parallel from the midline of the spine over the muscle. Ground electrode was placed over the midline of the lumbosacral bony landmark (Fig. 1) (Silva et al., 2020; Criswell, 2011).

\section{Statistical analysis}

The "Consensus for Experimental Design in Electromyography-2020" (CEDE) project provided the recommendations and guidelines for recording, analysis, interpretation and specific applications of EMG, published in the Journal of electromyography and kinesiology (International Society of Electrophysiological Kinesiology) (Besomi et al., 2020) reported to use non-maximal voluntary isometric contraction induced non-normalized sEMG data for interpretation as no method available for sEMG normalization in study dealing with pediatric population. Therefore sEMG signals (non-normalized) were used for fatigue analysis as per the instructions given by Besomi et al. (2020) and Halaki et al. (2012). The relative sizable inter-individual variability in the global core muscle activation pattern would be due to the diversity of anatomical and fiber type distributions. Therefore LOG(10) transformation procedures were applied for all sEMG Parameters and the alteration of sEMG activity of these three muscles was analyzed separately (Falla \& Farina, 2007) as between muscle activity could not possible to calculate with non-normalized sEMG data (Besomi et al., 2020).

For the Normality distribution assumption, the ShapiroWilk test was used and a significant ( $\mathrm{p} \leq 0.05)$ value would be considered as the departure from normality. Separate oneway repeated measures ANOVA was used to test the differences across the pre-, during and post fatigue with relative alteration of different sEMG parameters of EO, RA, ES muscles, N.LF ratio for RA (Agonist)/ ES (Antagonist), RA (Agonist)/ EO (Synergist) muscles and plank/endurance time $\left(\mathrm{T}_{\text {lim }}\right)$. For each ANOVA, if those parameters were found significantly distinguishable, Bonferroni corrected paired t-test was used to identify differences (Post Hoc) for pairwise comparison. In case the assumptions for parametric statistics were not 
met, nonparametric one-way Friedman ANOVA was used and statistically significant values were further analyzed with Dunn-Bonferroni test for multiple pairwise comparisons. The Sphericity assumption was tested by Mauchly's test and a significant ( $\mathrm{p} \leq 0.05)$ value would be considered as sphericity violation. The sphericity violation was treated with an appropriate degree of freedom (df) correction by applying either Greenhouse-Geisser $(\varepsilon<0.75)$ or Huynh-Feldt $(\varepsilon>0.75)$ correction. The level of significance was set at $\mathrm{p} \leq 0.05 . \eta_{\mathrm{p}}{ }^{2}$ was used as the effect size index. The values of $\eta_{\mathrm{p}}{ }^{2}$ were interpreted as small effect $(d=0.20)$, medium effect $(d=0.50)$ and large effect $(\mathrm{d}=0.80)$. For nonparametric Friedman ANOVA, Kendall's W coefficient was used for effect size, assuming the value from 0 (no relationship) to 1 (perfect relationship) (Silva et al. 2020).

The Pearson product-moment correlation coefficient (R) was used in normally distributed (LOG(10)-transformed, Shapiro-Wilk $\mathrm{p}>0.05$ ) data. The $\mathrm{R}$ value between an independent and dependent parameter was tested with bivariate linear regressions analysis (Verma, 2016) and it was performed between the Pre-Pre fatigue and Post-Post fatigue LOG(10) SD EMG- $(\mu \mathrm{V})$ with LOG $(10)$ ARV EMG- $(\mu \mathrm{V})$ of EO, RA, ES muscle separately. The Spearman correlation coefficient (r) of ARV EMG $(\mu \mathrm{V})$ with Endurance time $\left(\mathrm{T}_{\text {lim }}-\mathrm{Sec}\right.$.) of EO, RA and ES muscle were applied for both in pre and post fatigue.

ICC Analysis: The Interclass correlation coefficient (ICC) within 95\% confidence interval with three consecutive measurements (without sEMG electrodes displacement), absolute-agreement and 2-way mixed-effect model was used for test-retest reliability in this present study, and the degree of reliability (ICC) estimation was based on the following guideline: 0.00 to 0.25 - little; 0.26 to 0.49 - low; 0.50 to 0.69 - moderate; 0.70 to 0.89 - high and 0.90 to 1.00 - very high reliability (Silva et al., 2020; Mathur, Eng, \& MacIntyre, 2005). IBM SPSS statistics for windows, version 20.0, (IBM Corp., Armonk, NY, USA) was used for Statistical analysis and graphical representations.

\section{Results}

The One-way Repeated ANOVA revealed a significant difference in the selected sEMG Parameters $(\mathrm{p} \leq 0.05)$ with low to large effect sizes $\left(\eta_{\mathrm{p}}^{2}\right)$ (Table 1$)$. Larger effect sizes in selected sEMG Parameters were observed when compared with the baseline in the muscles with steeper fatigue level during repetitive fatiguing plank.

The predictive Linear regression model reveled (Fig. 4): A. For EO muscle the Pre fatigue showed significant $\mathrm{p}=0.001$, linear steepness $\left[\mathrm{R}=0.84, \mathrm{R}^{2}=0.70, \mathrm{~F}_{(1,10)}=23.68\right.$, $y=1.02 x+(-0.60)]$, for post fatigue model $p=0.009[R=0.72$, $\left.\mathrm{R}^{2}=0.51, \mathrm{~F}_{(1,10)}=10.44, \mathrm{y}=0.68 \mathrm{x}+0.06\right]$. B. For RA muscle the Pre fatigue $\mathrm{p}=0.002$, linear steepness $\left[\mathrm{R}=0.80, \mathrm{R}^{2}=0.64\right.$, $\left.\mathrm{F}_{(1,10)}=17.91, \mathrm{y}=0.82 \mathrm{x}+(-0.29)\right]$, Post fatigue $\mathrm{p}=0.001[\mathrm{R}=$ $\left.0.82, \mathrm{R}^{2}=0.67, \mathrm{~F}_{(1,10)}=20.09, \mathrm{y}=0.78 \mathrm{x}+(-0.19)\right]$. C. For the ES muscle Pre fatigue $\mathrm{p}=0.004$, linear steepness $[\mathrm{R}=0.76$, $\left.\mathrm{R}^{2}=0.58, \mathrm{~F}_{(1,10)}=13.67, \mathrm{y}=0.75 \mathrm{x}+(-0.14)\right]$ but for Post fatigue model the $\mathrm{p}=0.457$, linear flatness $\left[\mathrm{R}=0.24, \mathrm{R}^{2}=0.06\right.$, $\left.\mathrm{F}_{(1,10)}=0.59, \mathrm{y}=0.4 \mathrm{x}+0.11\right]$.

Table 1. The Summary of Endurance/Time-to-task and sEMG values across muscles during three consecutive fatiguing plank. The mean value of rectified EMG amplitude increased for EO, RA, ES muscles. The standard deviation of amplitude and Total Spectral power increased for all muscles except ES muscle. Power at Normalized Low Frequency changed in ES muscle. changes in Normalized Low Frequency for Agonist (RA)/Synergist (EO) and Agonist (RA)/ Antagonist (ES) muscles is also observed.

\begin{tabular}{|c|c|c|c|c|c|c|c|}
\hline & & PLANK & & & & & \\
\hline & $1 \mathrm{st}$ & 2nd & 3rd & & & & \\
\hline Variables & $\mathrm{M} \pm \mathrm{SD}$ & $\mathrm{M} \pm \mathrm{SD}$ & $\mathrm{M} \pm \mathrm{SD}$ & F-value & p-value & $\eta_{p}^{2}$-value & $\begin{array}{l}\text { ICC- } \\
\text { value }\end{array}$ \\
\hline $\mathrm{T}_{\lim }(\mathrm{SEC} .)^{\S}$ & $56.50 \pm 21.07$ & $70.50 \pm 25.36$ & $71.50 \pm 14.06$ & $1.17^{\dagger}$ & 0.56 & $0.05^{\dagger \dagger}$ & 0.06 \\
\hline EO ARV & $1.73 \pm 0.19$ & $1.78 \pm 0.17$ & $1.84 \pm 0.16$ & 24.76 & 0.00 & 0.69 & 0.96 \\
\hline EO SD EMG & $1.17 \pm 0.24$ & $1.26 \pm 0.18$ & $1.31 \pm 0.16$ & 4.46 & 0.02 & 0.29 & 0.83 \\
\hline EO N.LF & $1.78 \pm 0.08$ & $1.75 \pm 0.17$ & $1.78 \pm 0.09$ & $0.40^{*}$ & 0.56 & 0.04 & 0.58 \\
\hline EO TSP & $2.53 \pm 0.50$ & $2.67 \pm 0.41$ & $2.82 \pm 0.33$ & 5.09 & 0.02 & 0.32 & 0.86 \\
\hline$\overline{\text { RA ARV }}$ & $1.55 \pm 0.21$ & $1.59 \pm 0.19$ & $1.69 \pm 0.22$ & $12.25^{* *}$ & 0.00 & 0.53 & 0.92 \\
\hline RA SD EMG & $0.98 \pm 0.21$ & $1.01 \pm 0.18$ & $1.13 \pm 0.21$ & 4.37 & 0.03 & 0.28 & 0.77 \\
\hline RA N.LF & $1.74 \pm 0.09$ & $1.74 \pm 0.16$ & $1.81 \pm 0.05$ & 2.45 & 0.11 & 0.18 & 0.36 \\
\hline$\underline{\text { RA TSP }}$ & $2.07 \pm 0.44$ & $2.19 \pm 0.31$ & $2.44 \pm 0.41$ & 6.13 & 0.01 & 0.36 & 0.72 \\
\hline$\overline{\text { ES ARV }}$ & $0.54 \pm 0.14$ & $0.55 \pm 0.14$ & $0.61 \pm 0.09$ & 3.65 & 0.04 & 0.25 & 0.85 \\
\hline ES SD EMG & $0.27 \pm 0.13$ & $0.26 \pm 0.09$ & $0.35 \pm 0.15$ & $3.51^{\dagger}$ & 0.17 & $0.15^{\dagger \dagger}$ & 0.31 \\
\hline ES N.LF & $1.77 \pm 0.09$ & $1.78 \pm 0.13$ & $1.67 \pm 0.09$ & 3.29 & 0.05 & 0.23 & 0.52 \\
\hline$\underline{\text { ES TSP }}$ & $0.35 \pm 0.29$ & $0.34 \pm 0.23$ & $0.76 \pm 0.72$ & $2.17^{\dagger}$ & 0.34 & $0.09^{\dagger \dagger}$ & 0.06 \\
\hline$\overline{\mathrm{RA} / \mathrm{EO} \text { N.LF }}$ & $0.97 \pm 0.05$ & $1.00 \pm 0.14$ & $1.02 \pm 0.05$ & $8.17^{\dagger}$ & 0.02 & $0.34^{\dagger \dagger}$ & 0.20 \\
\hline RA/ES N.LF & $0.98 \pm 0.06$ & $0.98 \pm 0.11$ & $1.09 \pm 0.07$ & $5.66^{\dagger}$ & 0.05 & $0.24^{\dagger \dagger}$ & 0.02 \\
\hline
\end{tabular}

NOTE: $T_{\text {lim }}$ - Time to task failure, ARV EMG - Average Rectified EMG, SD EMG - EMG Standard Deviation, TSP - Total Spectral power, N.LF - Normalized Low frequency, EO - External Oblique, RA - Rectus abdominis, ES - Erector Spinae. The Mean \pm SD. Nonparametric Friedman ANOVAs,$F(d f-2,22)$ (Nonparametric $\left.\chi^{2 \dagger}\right)$, p value, $\eta_{\mathrm{p}}{ }^{2}$ (Nonparametric Kendall's $\mathrm{W}^{\dagger \dagger}$ ), ICC values (95\%-CI). EO N.LF (Greenhouse-Geisser) F1.14, 12.52*, RA ARV (Greenhouse-Geisser) F 1.34, 14.78*. Significant $\mathrm{p} \leq 0.01,0.05$ in Bold. LOG(10) Transformation was applied for all the sEMG values of EO, RA and ES muscle 


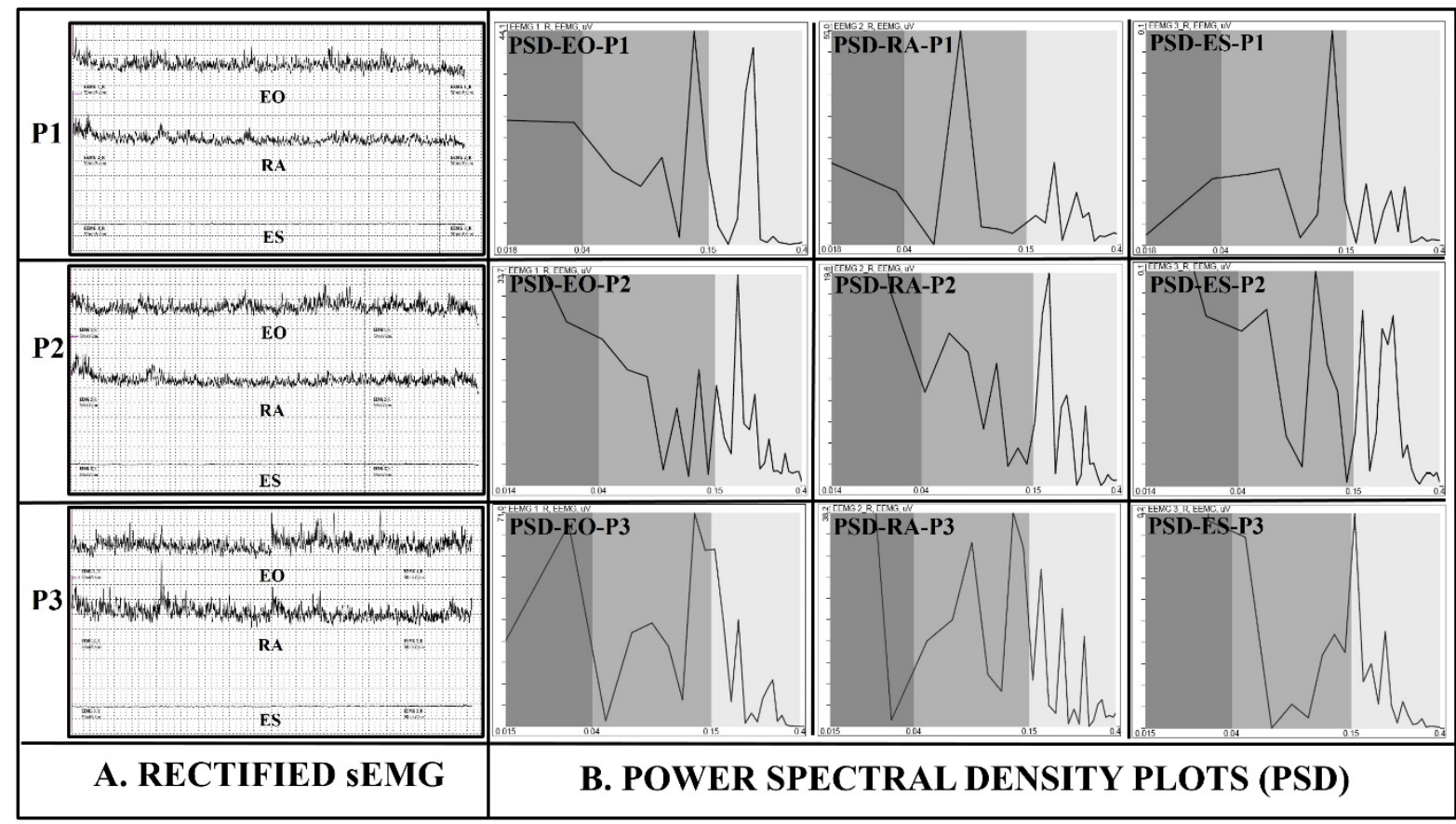

Fig. 2. Simultaneous sEMG activities were recorded of External Oblique (EO), Rectus abdominis (RA), Erector Spinae (ES) muscles during fatiguing isometric voluntary contraction. Continuous sEMG recordings for the entire time to task failure during three consecutive plank (P1, P2 and P3 respectively) holding test (with 3 minutes interval in between). A. sEMG signals were full-wave rectified, smoothed. B. Power spectral density plots were obtained from EO, RA, ES muscles during static fatiguing plank task. The energy changed only at normalized Low-frequency band of $10 \mathrm{~Hz}-70 \mathrm{~Hz}$ was taken for fatigue analysis.
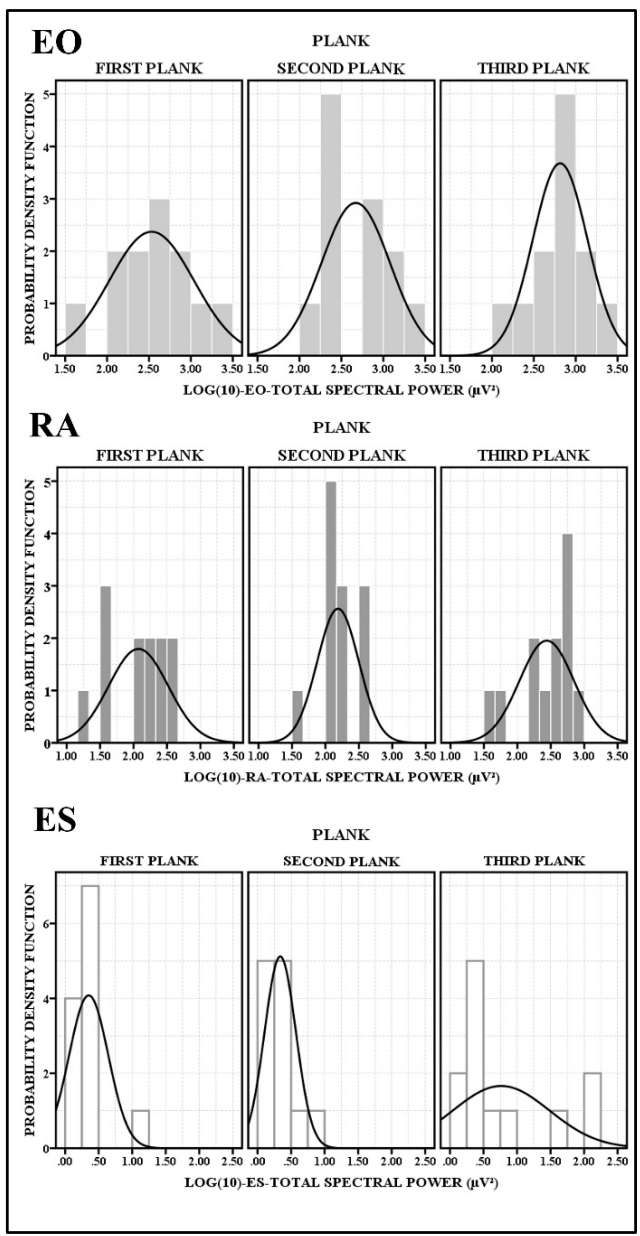

Fig. 3. Probability Density plots of $\log 10 \mathrm{TSP}$ of EO, RA and ES muscle during fatiguing plank. The pre to post fatigue EO log10TSP leptokurtic (0.182 vs. 1.374), RA log10TSP changed the kurtosis pattern (-1.202 vs. 0.975) also, and ES LOG(10)TSP platykurtic (7.884 vs. 0.016 ) transition observed.

The Spearman correlation coefficient (r) of ARV EMG $(\mu \mathrm{V})$ of EO, RA and ES muscle were not significantly correlated with Endurance time $\left(\mathrm{T}_{\text {lim }}-\mathrm{Sec}\right.$.) both in pre and post fatigue as the EO pre $r=0.39(p=0.22)$ vs. post $r=-0.494$ $(\mathrm{p}=0.103)$; RA pre $\mathrm{r}=0.30(\mathrm{p}=0.34)$ vs. post $\mathrm{r}=-0.501$ $(\mathrm{p}=0.097)$; and ES pre $\mathrm{r}=0.26(\mathrm{p}=0.42)$ vs. post $\mathrm{r}=-0.385$ $(\mathrm{p}=0.216)$ at $5 \%$ significance level.

Discussion of Hypotheses: According to the research hypotheses, some of the most important observations were that during sustained fatiguing contraction/plank the sEMG amplitude and the Total Spectral Power of the signal increased rapidly (Fig. 2A), power spectra intensified/shifted towards low frequency power spectra (inflation in low frequency band) (Fig. 2B). The positive linear relationship between average amplitude values with amplitude standard deviations of the sEMG signal was altered by fatigue (Fig. 4). The nonsignificant relationship between the time to task failure with sEMG amplitude was influenced by complex multiarticular joint function.

\section{Discussion}

The myoelectric manifestations of muscle fatigue are diverse and depend on several complex physiological factors which make it difficult to understand. The findings of this present study revealed that the acute adaptation to fatigue 


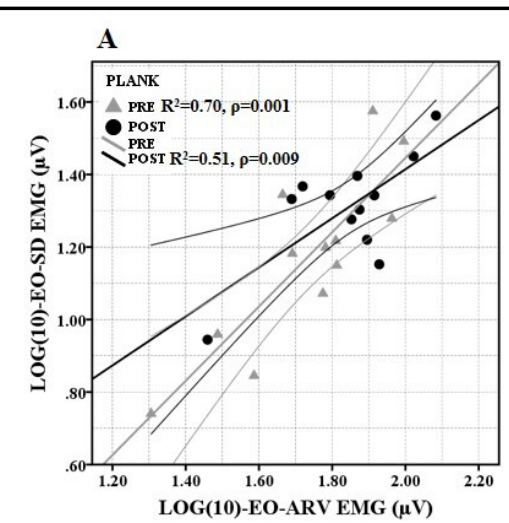

EO MUSCLE

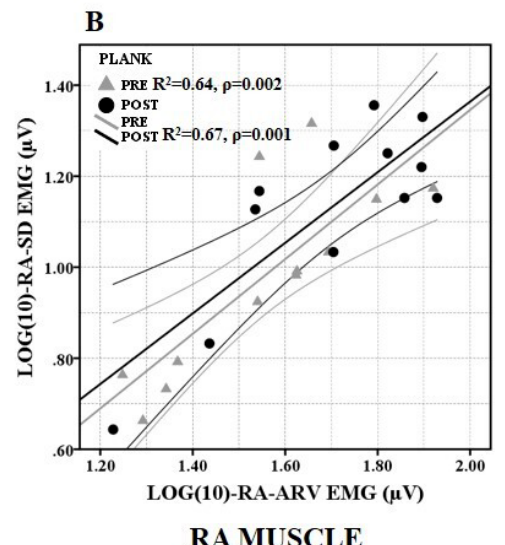

RA MUSCLE

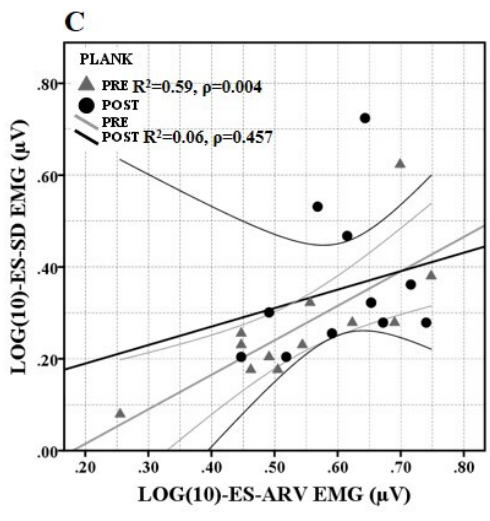

ES MUSCLE

PRE/PRE-POST/POST FATIGUE

Fig. 4. LOG(10)-Indicates Logarithm with base 10. Linear regression model between pre fatigue LOG(10) ARV EMG ( $\mu$ V) with LOG(10) SD EMG $(\mu \mathrm{V})$ and post fatigue LOG(10) ARV EMG $(\mu \mathrm{V})$ with $\operatorname{LOG}(10)$ SD EMG $(\mu V)$ of EO,

RA and ES muscle $(\mathrm{p} \leq 0.05)$

by altered muscle activation pattern intended to compensate the force reduction (Shrawan et al., 1996). Statistical significance $\mathrm{p}$-value with effect size $\eta_{\mathrm{p}}{ }^{2}>0.22$ indicates a more pronounced or meaningful fatigued state (Table 1) (Jacobs, Uhl, Seeley, Sterling, \& Goodrich, 2005).

Increased sEMG amplitude (Fig. 2 A, Table 1) resulted from rapid additional motor unit recruitment and rate coding. During fatiguing contraction, additional motor units recruited progressively as per Henneman's sizes principle. Firing off these motor units interfere and briefly inhibit the firing rate of previously recruited motor units, which might increase the variability (Table 1).

The concept of stretch reflex inflation during a postural fatiguing task is based on some basic theory: 1 . The rapidly deteriorating in the inhibition of presynaptic transmission and feedback modulation by Ia afferents group. 2. Active dendritic actions modulated by descending pathway and supraspinal drive 3 . Increase in motoneuronal $\alpha-\gamma$ coactivation. More pronounced postsynaptic than presynaptic activation mechanism was reported during fatigue if the pressor response absent. The motor neuron excitability during postural fatiguing task-induced pressor response activation was influenced by: 1. Group III-IV afferent input acquired by interneurons which excited the $\gamma$-motor neurons (Maluf \& Enoka, 2005). 2. Variations in motor unit firing rate and recruitment pattern, increased synchronization, most importantly decreased muscle fiber conduction velocity, all of these factors might be acted as a compensatory mechanism during fatigue-induced force loss among muscles. It might change the shape of the action potential (Fig. 2), increase the magnitude (Mean) and Variation (SD) of ARV amplitude (Table 1). The primary effects of motor-unit synchronization were proposed during fatigue as: Augmentating the magnitude and variability of AVR EMG (intense-synchrony condition), intensification of low frequency in EMG power spectra, attenuation of the cancellation in overlapped positive and negative phases of action potentials (Yao, Fuglevand, \& Enoka, 2000). Predominant muscle fiber-type (Type-I, 57-62\%) and recruitment strategies (viz. increased motor-unit synchronization and decreased propagation velocity) of motor units might also be responsible for sEMG Spectral power alteration and amplitude augmentation. The motor units of type I (low threshold) muscle fiber generates action potentials with higher power at the lower frequency during fatiguing contraction. Both the myoelectric signal of muscle tissue and surface EMG electrodes act as low-pass filters, rapid energy of the signal travel through the tissue when the lower frequency intensifies or prominent leftward shift (Fig. 2) in signal eventuated in the power spectrum during fatigue (Fig. 2B) (Hagberg, 1981). Ischemia resulted from hemodynamic occlusion therefore anaerobic glycolysis during isometric contraction increases the production of lactate, pyruvate, inorganic $\mathrm{Pi}$, resulted in intramuscular $\mathrm{pH}$ and conduction velocity to reduce. Studies reported lacking the significance of lactate production during fatiguing contraction proposed extracellular $\mathrm{K}+$ accumulation and $\mathrm{Na}+$ depletion in extracellular space could be the possible reason for sEMG signal alteration during fatigue (Linssen, Stegeman, Joosten, Binkhorst, Merks, Ter Laak, \& Notermans, 1991).

Relatively less prominent antagonist muscle activity (Fig. 2A) during the positional task was controlled by spinal interneurons, which further influenced by descending pathways to enhance the stability at the multiarticular joint level. The concurrent augmentation of agonist/synergistic ( $p$ $=0.02)$, agonist/antagonist $(\mathrm{p}=0.05) \mathrm{N}$. LF ratio (Table 1$)$ during fatigue resulted from either supraspinal descending drive or differentiated motor neuronal pool. The changes in excitability of motor neuronal pool in antagonist muscle usually observed with a substitute spinal pathway of disynaptic reciprocal inhibition from muscle's spindle afferents to the motor neurons as fatigue developed. An increase in sEMG amplitude ( $\mathrm{p}=0.04)$ of antagonist muscle stipulated a net increase in excitatory synaptic input to the spinal motor neurons and inherent characteristics of supraspinal mechanisms modulated by Ia presynaptic inhibition which further influenced different peripheral inputs parallelly as fatigue progressed. Researchers often reveal doubts about the reliability of antagonist sEMG (Low ICC in ES muscle) (Table 1). But with strict sEMG recordings protocol, it may produce an acceptable and meaningful antagonist coactivation even 
though the signal does not dispense a precise estimate of its mechanical contribution (Duchateau \& Baudry, 2014). The modulation of antagonist coactivation during fatiguing contraction might extend the $\mathrm{T}_{\text {lim }}(\mathrm{p}=0.56)$ (Table 1) (Shrawan et al., 1996). Motor units that innervate the number of muscle fibers reveal a Non-Gaussian distribution in sEMG Spectral power, uniquely the LOG(10)TSP showed unique alteration of kurtosis pattern among three muscles across the three consecutive fatiguing plank also might extend the $\mathrm{T}_{\text {lim }}$ (Fig. 3).

The failure to detect any statistically significant difference $(p>0.05)$ in sEMG parameters (Table 1) during fatiguing contraction might falsely be concluded as no specific alteration of rate coding and motor-unit activity. It was also possible that sEMG amplitude or power spectral frequency might show a lower potential to identify small changes efficiently of the neural drive against time of muscles with multiarticular joints functions, which further affected by signal contamination due to volume conduction, cross talk and electromagnetic interferences (Farina, Arendt-Nielsen, Merletti, \& Graven-Nielsen, 2004). Although more repetitions with less resting or interval periods during standardized exercise (Kapkan, Khudolii, \& Bartík, 2019) may increase the chance for significant sEMG signal alteration due to fatigue at this age group of this present study. Further studies where the children are involved in different exercise interventions may use different sEMG parameters with cautions to observe neural recruitment strategies alteration, overload/muscle fatigue level and training progression.

The average amplitude values of the sEMG signals usually have Gaussian probability distribution, often show a linear relationship with sEMG amplitude standard deviations of the signals. We also observed the average sEMG amplitude value produced a steeper and linear relationship with the amplitude variability with the relative alteration of the relationship from pre to post fatigue state of three core muscle (Fig. 4). Henneman's size principle stated small motor units (low recruitment threshold) have initial fatigue response, recruited to fire at low force level, shows small variability, where the larger motor units (high recruitment threshold) recruited at higher fatigue level indicated large variability. The subjects with larger variability showed a longer time to task capacity with more heterogeneous muscle activation pattern and smaller localized muscle fatigue. The neuronal mean firing rate alters sinusoidally and variability in spike generation is proportionately related to the mean firing rate during fatiguing contraction (Stein, Gossen, \& Jones, 2005).

The non-significant $(\mathrm{p}>0.05)$ Spearman correlation coefficient between the time to task failure with sEMG amplitude might influenced by multiarticular joint function, volume conduction, cross talk by the synergistic muscles or electrical interferences (Boyas, et al., 2009).

\section{Limitations}

Due to the complexity of MVIC induced sEMG amplitude normalization protocol for core muscle, clinicians usually avoid it, as it is also not recommended for the children less than 15 years age (Nicholson, 2000). The electromagnetic interferences, crosstalk by surrounding muscles could never be replaced completely but tried to reduce it with high signalto-noise ratio in sEMG setting.

\section{Conclusions}

Increased sEMG amplitude resulted from rapid additional motor unit recruitment and rate coding while performing the fatiguing plank task. Variation in motor unit firing rate and recruitment pattern, increased synchronization and deterioration in the muscle fiber conduction velocity, all of these factors influenced the shape of action potential and made the sEMG amplitude increase during fatigue. Recruitment strategies of motor units and predominant I-type muscle fiber, these two factors caused sEMG Spectral power to change and spectral shift towards low-frequency band during fatigue. The longer time to task or Endurance capacity was observed by heterogeneous muscle activity during isometric contraction. Postural fatiguing task/plank increases multiarticular joint function by involving several joints and muscles, increases variability in the contribution of synergist muscles. This factor provide an intuitive explanation about the absence of a relationship between endurance time and sEMG amplitude changes.

\section{Acknowledgement}

The authors acknowledge Mr. Vinay Verma, (CEO, Volant Technologies-New Delhi, India) who served as scientific advisor and technical assistant. The authors acknowledge volunteers of Ram Krishna Vidya Mandir Ashrama-Sharada Balgram, Gwalior (M.P.) India, for their active participation and data collection.

Funding: The authors report no involvement in the research by the sponsor that could have influenced the outcome of this work. This is a part of my self-funded Ph.D work [Reg. No.-PH2010-114].

\section{Conflict of interest}

The authors certify that there is no conflict of interest with any financial organization regarding the material discussed in the manuscript. We confirm that this work is original and has not been published elsewhere, nor is it currently under consideration for publication elsewhere. Furthermore, I accept responsibility for the scientific integrity of the work described in this manuscript. This paper was not presented as oral/poster at the any Congress or conference.

\section{References}

Campanini, I., Disselhorst-Klug, C., Rymer, W.Z., \& Merletti, R. (2020). Surface EMG in Clinical Assessment and Neurorehabilitation: Barriers Limiting Its Use. Frontiers in Neurology, 11, 934. https://doi.org/10.3389/fneur.2020.00934

Felici, F. \& Del Vecchio, A. (2020). Surface Electromyography: What Limits Its Use in Exercise and Sport Physiology? Frontiers in Neurology, 11, 578504. https://doi.org/10.3389/fneur.2020.578504

Ivashchenko, O.V., Cieślicka, M., Nosko, M.O., \& Malyshev, D. A. (2019). Motor Abilities: Peculiarities of Strength Effort Assessment in Boys Aged 11-13. Teoriâ ta Metodika Fizičnogo Vihovannâ, 19(1), 37-43. https://doi.org/10.17309/tmfv.2019.1.05 
Ivashchenko, O., Kapkan, O., Khudolii, O. \& Yermakova, T. (2017). Informative indicators of 14-15 years' age boys' motor fitness. Teoriâ ta Metodika Fizičnogo Vihovannâ, 17(2), 86-97. https://doi.org/10.17309/tmfv.2017.2.1193

Moalla, W., Merzouk, A., Costes, F., Tabka, Z., \& Ahmaidi, S. (2006). Muscle oxygenation and EMG activity during isometric exercise in children. Journal of sports sciences, 24(11), 1195-1201. https://doi.org/10.1080/02640410500457893

Khudolii, O.M., Ivashchenko, O.V., Iermakov, S.S., Veremeenko, V.Yu., \& Lopatiev, A.O. (2019). Motor Abilities: Identification of Development Level in Boys Aged 12-14. Teoriâ ta Metodika Fizičnogo Vihovannâ, 19(3), 139-147. https://doi.org/10.17309/tmfv.2019.3.05

Cardozo, A. C., Gonçalves, M., \& Dolan, P. (2011). Back extensor muscle fatigue at submaximal workloads assessed using frequency banding of the electromyographic signal. Clinical Biomechanics (Bristol, Avon), 26(10), 971-976. https://doi.org/10.1016/j.clinbiomech.2011.06.001

Gentil, P., Oliveira, E., de Araújo Rocha Júnior, V., do Carmo, J., \& Bottaro, M. (2007). Effects of exercise order on upperbody muscle activation and exercise performance. Journal of Strength and Conditioning Research, 21(4), 1082-1086. https://doi.org/10.1519/r-21216.1

Lindstrom, B., Stefan, K. J., \& Lexell, J. (2006). Isokinetic torque and surface electromyography during fatiguing muscle contractions in young and older men and women. Isokinetics and Exercise Science, 14(3), 225-234. https://doi.org/10.3233/IES-2006-0228

Gerdle, B., Karlsson, S., Crenshaw, A. G., Elert, J., \& Fridén, J. (2000). The influences of muscle fibers proportions and areas upon EMG during maximal dynamic knee extensions. European Journal of Applied Physiology, 81(12), 2-10. https://doi.org/10.1007/PL00013792

Grosset, J. F., Mora, I., Lambertz, D., \& Pérot, C. (2008). Voluntary activation of the triceps surae in prepubertal children. Journal of Electromyography and Kinesiology: Official Journal of The International Society of Electrophysiological Kinesiology, 18(3), 455-465. https://doi.org/10.1016/j.jelekin.2006.11.002

Kellis, E., \& Unnithan, V. B. (1999). Co-activation of vastus lateralis and biceps femoris muscles in pubertal children and adults. European Journal of Applied Physiology and Occupational Physiology, 79(6), 504-511. https://doi.org/10.1007/s004210050545

Boyer, C., Tremblay, M., Saunders, T. J., McFarlane, A., Borghese, M., Lloyd, M., \& Longmuir, P. (2013). Feasibility, Validity, and Reliability of the Plank Isometric Hold as a Field-Based Assessment of Torso Muscular Endurance for Children 8-12 Years of Age. Pediatric Exercise Science, 25(3), 407-422. https://doi.org/10.1123/pes.25.3.407

Patikas, D. A., Williams, C. A., \& Ratel, S. (2018). Exerciseinduced fatigue in young people: advances and future perspectives. European Journal of Applied Physiology, 118(5), 899-910. https://doi.org/10.1007/s00421-018-3823-1

De Blaiser, C., De Ridder, R., Willems, T., Danneels, L., Vanden Bossche, L., Palmans, T., \& Roosen, P. (2018). Evaluating abdominal core muscle fatigue: Assessment of the validity and reliability of the prone bridging test. Scandinavian Journal of Medicine \& Science in Sports, 28(2), 391-399. https://doi.org/10.1111/sms.12919

Duchêne, J., \& Goubel F. (1990). EMG spectral shift as an indicator of fatigability in an heterogeneous muscle group. European journal of applied physiology and occupational physiology, 61(1-2), 81-87. https://doi.org/10.1007/BF00236698

Silva, F. H. O., Arantes, F. J., Gregorio, F. C., Santos, F. R. A., Fidale, T. M., Bérzin, F., Bigaton, D. R., \& Lizardo, F. B. (2020). Comparison of the Electromyographic Activity of the Trunk and Rectus Femoris Muscles During Traditional Crunch and Exercise Using the 5-Minute Shaper Device. Journal of Strength and Conditioning Research, 34(1),1-10. https://doi.org/10.1519/JSC.0000000000003250

Merletti, R., De Luca, C. J., \& Sathyan, D. (1994). Electrically evoked myoelectric signals in back muscles: effect of side dominance. Journal of applied physiology, 77(5), 21042114. https://doi.org/10.1152/jappl.1994.77.5.2104

Adam, A., De Luca, C. J., \& Erim, Z. (1998). Hand dominance and motor unit firing behavior. Journal of neurophysiology, 80(3), 1373-1382. https://doi.org/10.1152/jn.1998.80.3.1373

Jacobs, C., Uhl, T. L., Seeley, M., Sterling, W., \& Goodrich, L. (2005). Strength and fatigability of the dominant and nondominant hip abductors. Journal of athletic training, 40(3), 203-206.

Cortell-Tormo, J. M., García-Jaén, M., Chulvi-Medrano, I., Hernández-Sánchez, S., Lucas-Cuevas, Á. G., \& TortosaMartínez, J. (2017). Influence of Scapular Position on the Core Musculature Activation in the Prone Plank Exercise. Journal of Strength and Conditioning Research, 31(8), 2255-2262. https://doi.org/10.1519/JSC.0000000000001689

Schoenfeld, B. J., Contreras, B., Tiryaki-Sonmez, G., Willardson, J. M., \& Fontana, F. (2014). An electromyographic comparison of a modified version of the plank with a long lever and posterior tilt versus the traditional plank exercise. Sports Biomechanics, 13(3), 296 306. https://doi.org/10.1080/14763141.2014.942355

Bohannon, R. W., Steffl, M., Glenney, S. S., Green, M., Cashwell, L., Prajerova, K., \& Bunn, J. (2018). The prone bridge test: Performance, validity, and reliability among older and younger adults. Journal of Bodywork and Movement Therapies, 22(2), 385-389. https://doi.org/10.1016/j.jbmt.2017.07.005

Héroux, M. E., Butler, A. A., Gandevia, S. C., Taylor, J. L., \& Butler, J. E. (2016). Time course of human motoneuron recovery after sustained low-level voluntary activity. Journal of Neurophysiology, 115(2), 803-812. https://doi.org/10.1152/jn.00950.2015

Criswell, E. (2011). Cram's introduction to surface electromyography (2nd Ed.). Jones and Bartlett PublishersLLC. 342-349 p.

Besomi, M., Hodges, P. W., Clancy, E. A., Van Dieën, J., Hug, F., Lowery, M., et al. (2020). Consensus for experimental design in electromyography (CEDE) project: Amplitude normalization matrix. Journal of Electromyography and 
Kinesiology: Official Journal of the International Society of Electrophysiological Kinesiology, 53, 102438.

https://doi.org/10.1016/j.jelekin.2020.102438

Halaki, M., \& Ginn, K. (2012). "Normalization of EMG signals: to normalize or not to normalize and what to normalize to," in Computational Intelligence in Electromyography Analysis-A Perspective on Current Applications and Future Challenges, ed. G. R. Naik. IntechOpen. 175-194. https://doi.org/10.5772/49957

Falla, D., \& Farina, D. (2007). Periodic increases in force during sustained contraction reduce fatigue and facilitate spatial redistribution of trapezius muscle activity. Experimental Brain Research, 182(1), 99-107. https://doi.org/10.1007/s00221-007-0974-4

Verma, J. P. (2016). Repeated Measures Design for Empirical Researchers. (1st Ed.). John Wiley and sons. 46 p.

Mathur, S., Eng, J. J., \& MacIntyre, D. L. (2005). Reliability of surface EMG during sustained contractions of the quadriceps. Journal of Electromyography and Kinesiology: Official Journal of the International Society of Electrophysiological Kinesiology, 15(1), 102-110. https://doi.org/10.1016/j.jelekin.2004.06.003

Shrawan, K., \& Anil, M. (Eds.). (1996). Electromyography in Ergonomics (2nd ed.). Taylor \& Francis. https://doi.org/10.1201/9780203758670

Maluf, K. S., \& Enoka, R. M. (2005). Task failure during fatiguing contractions performed by humans. Journal of Applied Physiology, 99(2), 389-396.

https://doi.org/10.1152/japplphysiol.00207.2005

Yao, W., Fuglevand, R. J., \& Enoka, R. M. (2000). Motor-unit synchronization increases EMG amplitude and decreases force steadiness of simulated contractions. Journal of Neurophysiology, 83(1), 441-452. https://doi.org/10.1152/jn.2000.83.1.441

Hagberg M. (1981). Muscular endurance and surface electromyogram in isometric and dynamic exercise. Journal of Applied Physiology: Respiratory, Environmental and Exercise Physiology, 51(1), 1-7. https://doi.org/10.1152/jappl.1981.51.1.1

Linssen, W. H., Stegeman, D. F., Joosten, E. M., Binkhorst, R. A., Merks, M. J., ter Laak, H. J., \& Notermans, S. L. (1991). Fatigue in type I fiber predominance: a muscle force and surface EMG study on the relative role of type I and type II muscle fibers. Muscle Nerve, 14(9), 829-837. https://doi.org/10.1002/mus.880140906

Duchateau, J., \& Baudry, S. (2014). The neural control of coactivation during fatiguing contractions revisited. Journal of Electromyography and Kinesiology: Official Journal of the International Society of Electrophysiological Kinesiology, 24(6), 780-788.

https://doi.org/10.1016/j.jelekin.2014.08.006

Farina, D., Arendt-Nielsen, L., Merletti, R., \& Graven-Nielsen, T. (2004). Effect of experimental muscle pain on motor unit firing rate and conduction velocity. Journal of Neurophysiology, 91(3), 1250-1259. https://doi.org/10.1152/jn.00620.2003

Kapkan, O.O., Khudolii, O.M., \& Bartík, P. (2019). Motor Skills Development: Optimization of Teaching Boys Aged 14. Teoriâ ta Metodika Fizičnogo Vihovannâ, 19(3), 148-155. https://doi.org/10.17309/tmfv.2019.3.06

Stein, R. B., Gossen, E. R., \& Jones, K. E. (2005). Neuronal variability: noise or part of the signal? Nature reviews Neuroscience, 6(5), 389-397. https://doi.org/10.1038/nrn1668

Boyas, S., Maïsetti, O., \& Guével, A. (2009). Changes in sEMG parameters among trunk and thigh muscles during a fatiguing bilateral isometric multi-joint task in trained and untrained subjects. Journal of Electromyography and Kinesiology: Official Journal of the International Society of Electrophysiological Kinesiology, 19(2), 259-268. https://doi.org/10.1016/j.jelekin.2007.09.002

Nicholson, W. R. (2000). The Importance of Normalization in the Interpretation of Surface Electromyography: A Proof of Principle. Journal of Manipulative and Physiological Therapeutics, 23(5), 369-370.

\section{ОЦІНКА МІОЕЛЕКТРИЧНИХ ПРОЯВІВ М'ЯЗОВОЇ ВТОМИ ПІД ЧАС ПОВТОРНИХ ІЗОМЕТРИЧНИХ ДОВІЛЬНИХ СКОРОЧЕНЬ У ХЛОПЧИКІВ У ВІЦІ 12-14 РОКІВ}

\section{Абір Саманта ${ }^{1 \mathrm{ABCD}}$, Саб’ясачі Мукерджі ${ }^{1 \mathrm{AD}}$ \\ ${ }^{1}$ Національний інститут фізичного виховання імені Лакшмі Бай}

Авторський вклад: А - дизайн дослідження; В - збір даних; C - статаналіз; D - підготовка рукопису; Е - збір коштів

Реферат. Стаття: 11 с., 4 рис., 1 табл., 41 джерело.

Мета дослідження - вивчити особливості чергування характеристик сигналів електроміографії за допомогою різних параметрів sEMG під час повторного довільного ізометричного втомлюючого скорочення у хлопчиків-підлітків.

Матеріали і методи. У дослідженні брали участь 12 випробовуваних (зріст - 148,75 \pm 10 см; маса тіла - 38,9 \pm 7,9 кг; вік - від 12 до 14 років). Аналізували зміну сигналу sEMG зовнішнього косого, прямого м'язів живота, м'язів Erector Spinae під час тесту планка на виснаження. Окремі односторонні повторні вимірювання ANOVA використовували для тестування статистичної значущості часу виконання завдання та параметрів електроміографії сумарної активності м'язів перед, під час та після тесту планка на виснаження. Односторонній метод Friedman ANOVA застосовувався 
для Шапіро-Вілка $\mathrm{p}<0,05$. Коефіцієнт кореляції продуктумоменту Пірсона 3 аналізом двовимірної лінійної регресії проводили між середнім значенням амплітуди стомлення до попереднього та попереднього часу та стандартними значеннями девіації. Розраховувався коефіцієнт кореляції Спірмена між амплітудою та часом витривалості як у стані до, так і після втоми.

Результати. Середнє значення випрямленої амплітуди збільшилось для всіх м'язів ( $<0,05)$, стандартне відхилення амплітуди та загальної спектральної потужності значно зросло для всіх м'язів $(\mathrm{p}<0,05)$, крім м'язів Erector Spinae ( $\mathrm{p}>0,05)$. Потужність при нормалізованій низькій частоті суттєво змінилася у м'язі Erector Spinae $(\mathrm{p}=0,05)$. Спостерігалися суттєві зміни нормалізованої низької частоти для м'язів агоністів / синергістів $(\mathrm{p}=0,02)$ та м'язів агоністів / антагоністів $(\mathrm{p}=0,05)$. Середнє значення амплітуди мало значущу позитивну та лінійну залежність від варіабельності амплітуди як до стану після втоми, за винятком м'язів
Erector Spinae. Час до невиконання завдання не корелював ( $>$ > 0,05) з амплітудою sEMG.

Висновки. Збільшення амплітуди sEMG відбулося в основному внаслідок швидкого набору додаткових рухових одиниць та швидкості кодування під час втоми м'язів. Зменшення швидкості провідності може вплинути на спектральну потужність із спектральним зсувом у бік низькочастотних. Підвищена мінливість, спільна активність агоніста / антагоніста під час втомлюючого скорочення може продовжити час витримки. Постуральне втомлювальне завдання / планка збільшує багатосуглобову суглобову функцію, залучаючи кілька суглобів і м’язів, збільшуючи мінливість внеску синергічних м'язів. Цей фактор дає інтуїтивне пояснення відсутності зв'язку між часом витривалості та змінами амплітуди sEMG.

Ключові слова: рухова одиниця, блок кодування, швидкість провідності.

\section{Information about the authors:}

Samanta Abir: abirphyyoga137@gmail.com; https://orcid.org/0000-0002-6530-9514; Lakshmibai National Institute of Physical Education, Department of Exercise Physiology, Shaktinagar, Mela Road, Gwalior, Madhya Pradesh, Pin Code-474002, India.

Mukherjee Sabyasachi: mukherjee.mukherjee37@gmail.com; https://orcid.org/0000-0002-4172-2144; Lakshmibai National Institute of Physical Education, Vice Chancellor (Officiating), Shaktinagar, Mela Road, Gwalior, Madhya Pradesh, Pin Code-474002, India.

Cite this article as: Samanta, A., \& Mukherjee, S. (2021). Assessment of Myoelectric Manifestations of Muscle Fatigue During Repetitive Isometric Voluntary Contraction in Boys Aged 12-14. Teoriâ ta Metodika Fizičnogo Vihovannâ, 21(1), 50-60. https://doi.org/10.17309/tmfv.2021.1.07

Received: 31.12.2020. Accepted: 20.03.2021. Published: 25.03.2021

This work is licensed under a Creative Commons Attribution 4.0 International License (http://creativecommons.org/licenses/by/4.0). 